\title{
A generic approach for simulation of large earthquakes
}

\author{
B. Fälth ${ }^{1}$, H. Hökmark ${ }^{1} \&$ R. Munier ${ }^{2}$ \\ ${ }^{I}$ Clay Technology AB, Sweden \\ ${ }^{2}$ Swedish Nuclear Fuel and Waste Management Co., Sweden
}

\begin{abstract}
This paper presents a generic modeling approach to estimate the possible static and dynamic effects of an earthquake on a deep repository for spent nuclear fuel. 3D models, including a discrete fault plane and numerous surrounding fractures, are analyzed dynamically with $3 D E C$. An algorithm to control the rupture initiation and the following propagation along the fault plane is developed. Model geometries, the mechanical properties of fault and rock, and the in-situ stresses are calibrated to give the intended seismic moment. M5 and M6 events are simulated with models where the complete fault plane is included (full 3D models). In order to simulate larger earthquakes (M7.5), quasi-3D models with truncated fault planes are developed. The relevance and conservativeness of the models are assessed by comparison of the resulting fault movement and ground motions with data found in the literature.
\end{abstract}

Keywords: modeling, repository, seismic attenuation, stress drop, slip velocity.

\section{Introduction}

In the KBS-3 concept for geological disposal of spent nuclear fuel, applied by the Swedish Nuclear Fuel and Waste Management Company (SKB), copper canisters with a cast iron insert containing the fuel are deposited in vertical deposition holes at 400-700 $\mathrm{m}$ depth in crystalline rock (fig. 1(a)). The canisters are surrounded by a bentonite clay buffer for isolation and mechanical protection [1]. Large shear displacements along a fracture intersecting a canister could obviously damage the canister, in particular if the fracture shear velocity is high (fig. 1(b)). In SKB's safety assessment, canisters sheared $100 \mathrm{~mm}$ or more count as failed [1]. 


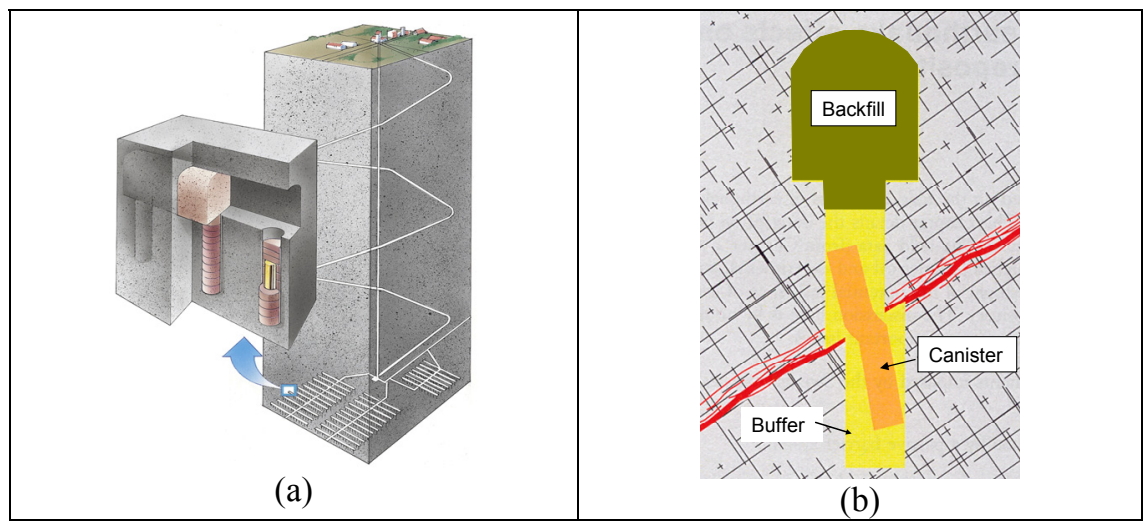

Figure 1: (a) Illustration of the KBS-3 concept and (b) shearing of fracture intersecting a deposition hole.

Although Sweden presently is an area of low seismicity [2] it is generally agreed that large earthquakes (about M8) have occurred in Sweden in connection with the retreat of the latest ice cover some 10,000 years ago [3-5]. While all unambiguous traces of such large postglacial earthquakes appear to be located in northern Scandinavia where the ice cap was thickest and had the longest unbroken duration, it cannot be entirely excluded that some may have occurred also in central and southern Sweden [6]. This means that there may be a potential risk of postglacial earthquakes occurring close to the candidate repository sites in connection with the retreat of future ice-covers and that the probability of canisters being damaged, for instance as shown in fig. $1 \mathrm{~b}$, must be assessed. This paper presents a generic modeling method of estimating the possible static and dynamic effects on the deep repository, in terms of fracture displacements, induced by a nearby postglacial earthquake. The results described and discussed here are based on work reported [7] and work in progress [8].

\section{Modeling approach}

\subsection{General}

The models described below were created and analyzed by using version 3.0 of the three-dimensional distinct element code $3 D E C .3 D E C$ is developed specifically to model mechanical and thermo-mechanical processes in media containing numerous intersecting discontinuities such as jointed rock masses and employs an explicit time-stepping solution scheme [9]. A large discontinuity representing a pre-existing potential earthquake fault (the "primary fault") and a number of smaller discontinuities ("target fractures") were defined. The target fractures represented fractures in which slip potentially may be induced by the earthquake. In-situ stresses were applied and a rupture was initiated and programmed to propagate along the plane of the primary fault, resulting in fault 
slip and accompanying strain energy release. This approach made it possible to study the target fracture shear displacements induced by static stress redistribution as well as by dynamic oscillations.

\subsection{Model outlines}

Due to memory allocation limitations, events larger than about M6 cannot be fully modeled using $3 D E C$, version 3.0 [7]. In order to model larger earthquakes, a technique for truncation of the models was developed. Fig. 2, left shows the outlines of full M5.5 and M6.2 models and a truncated M7.5 model. The M7.5 model is a thick slice of a rock volume intersected by a fault large enough to host a M7.5 earthquake. Using a truncated model implies that the rupture length, $L$, is automatically assumed to be much larger than the rupture width, w. A truncated model will not be able to capture the response around the fault edges and it will not give fully accurate results a few seconds after rupture initiation [8]. However, the model width of the truncated models was set large enough that irrelevant reflections in the truncation plane did not influence the region close to the symmetry plane where the target fractures were located. At $500 \mathrm{~m}$ depth numerous circular target fractures were defined. All target fractures had $150 \mathrm{~m}$ radius and strength properties according to site investigation data $[10,11]$. The upper boundary represented the ground surface.

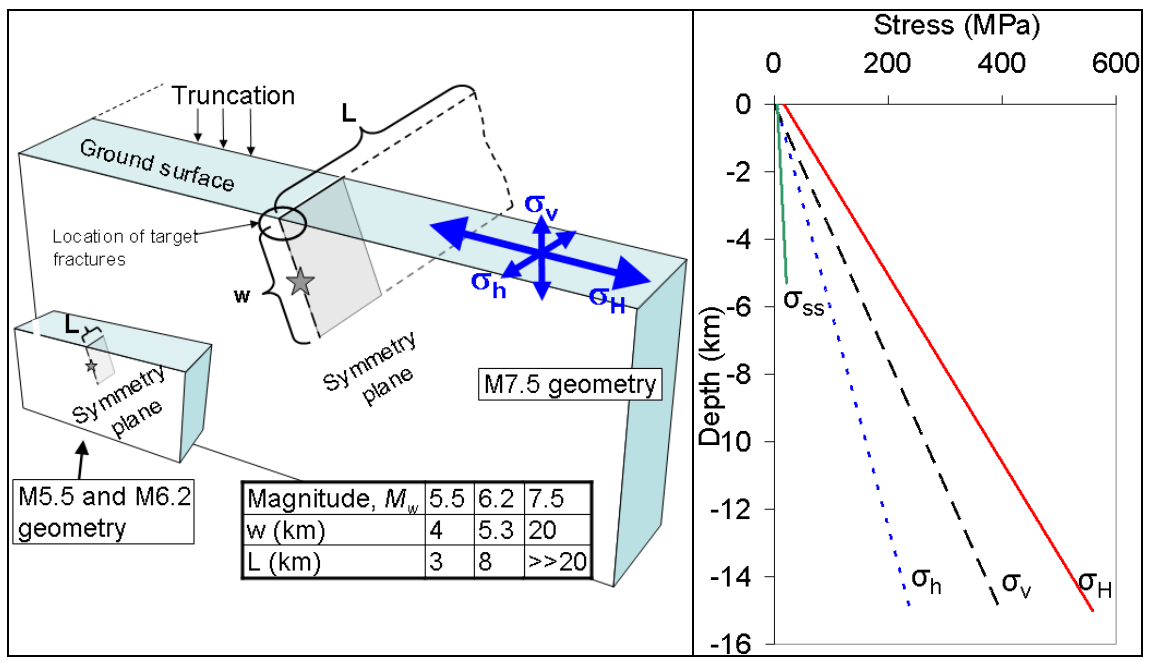

Figure 2: $\quad$ Left: model geometry outlines of the full M5.5 and M6.2 models and the truncated M7.5 model. The star indicates the hypocenter location. Right: in-situ stress components in M5.5 and M6.2 models and corresponding initial fault shear stress $\sigma_{s s}$.

The dimensions of the primary fault were specified to give a rupture area large enough to host an earthquake of the intended moment magnitude. The basic 
assumption was a fault dip angle of $70^{\circ}$, but $30^{\circ}$ was also used in some M5.5 models. The continuum was assumed to be linearly elastic with generic parameter values; Young's modulus $75 \mathrm{GPa}$, Poisson's ratio 0.25 and density $2700 \mathrm{~kg} / \mathrm{m}^{3}$.

Postglacial, or end-glacial, stress states are characterized by high horizontal stresses which are due to down-warping and/or tectonic strain accumulated under the stabilizing ice cover, whereas the vertical stress corresponds to the rock overburden $[5,12,13]$. Here, the major initial horizontal stress was oriented normally to the fault strike and calibrated to give the average fault displacement needed to obtain the intended seismic moment. For the geometry assumed here the minor horizontal stress is not important to the fault behavior. The horizontal and vertical stress components were taken to be principal stresses (fig. 2, left). Fig. 2, right, shows the stresses as function of depth as assumed in the M5.5 and M6.2 models.

The analyses comprised of two phases: Static phase and Dynamic phase. During the static phase all boundaries, except for the free top boundary, were locked for normal displacements (roller boundaries). During the dynamic phase, all boundaries with exception of the top boundary, which was free to allow for surface reflections, the symmetry plane and the truncation plane (magnitude 7.5 only, cf. fig. 2) which were locked in the normal direction, were viscous, i.e. non-reflecting.

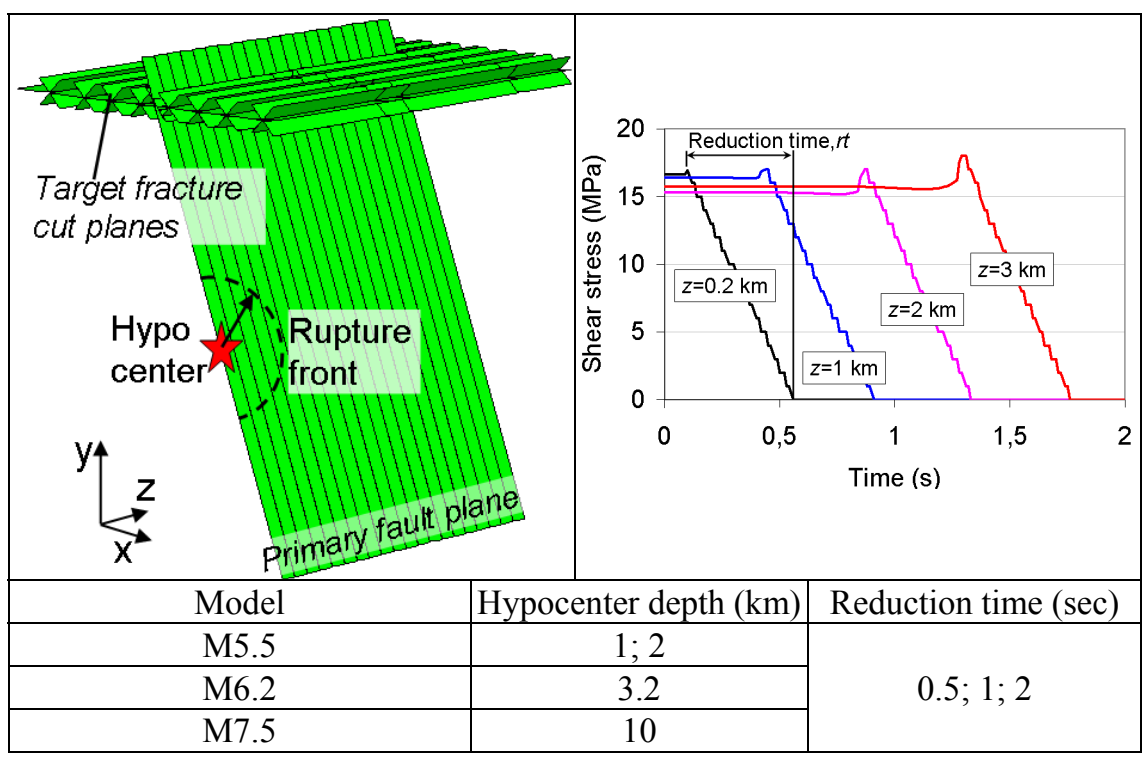

Figure 3: Top: rupture propagation along the primary fault and fault shear stress histories at hypocenter depth in M6.2 model. Bottom: parameter values for the different models. 


\subsection{Initiation and propagation of the rupture}

During the static phase, the cohesive strength assigned to the fault was set high enough to prevent slip and static equilibrium was established under the initial stresses. During the dynamic phase, a scheme for rupture initiation and propagation was applied. The principle for rupture propagation is illustrated in fig. 3, upper left. The rupture was initiated at the hypocenter located at the symmetry plane (cf. fig. 2) and was programmed to move outwardly in the radial direction along the primary fault. At every time-step, the cohesive strength of each sub-contact in the fault was updated to match the shear stress currently acting at that particular location. Upon rupture front arrival, the shear strength of the sub-contacts was ramped down to zero (or to a specified residual strength) over a specified period of time (here denoted Reduction time, $r t$ ). The basic assumption was to have zero residual strength but a friction angle of $6^{\circ}$ was used in some M5.5 models. The strength ramping is illustrated by the shear stress curves in fig. 3, upper right. The curves represent four points located at hypocenter depth at different distances from the hypocenter in a M6.2 model. The curves show how the cohesive strength is ramped down to zero at every point. A zero residual shear strength in the primary fault resulted in a net stress drop equal to the shear stress initially acting on the fault (cf. fig. 2, right). The parameter values used in the different models are shown at the bottom of fig. 3 . The rupture propagation velocity was set at $70 \%$ of the elastic shear wave velocity.

\section{Results}

This section presents result examples from the models. The objective here was not to present a complete set of results but merely to demonstrate the modeling technique and to assess the relevance of that technique.

\subsection{Fault displacements}

In fig. 4, top, shear displacement vector plots at three instances of time in a M6.2 model are shown. The rupture is initiated at the hypocenter and propagates in the radial direction. After about 2.5 seconds, the rupture is complete. The maximum resulting fault slip at the ground surface is about $3 \mathrm{~m}$. The temporal evolution of slip is shown in the lower left diagram. The curves show the fault displacements at four points at hypocenter depth. The point locations are indicated by dots in the upper left plot. It can be observed how the slip is initiated at different instances of time as the rupture front propagates. Due to the zero residual fault friction there are some large oscillations before the model comes to rest. The lower right diagram shows the resulting fault slip distribution along a scan-line in the down-dip direction in three models. When studying this diagram it becomes clear how the idealized assumption with zero (or low) residual fault friction gives an idealized slip distribution with its maximum always at the ground surface. The shapes of the curves are governed also by the in-situ stress distributions. 


\subsection{Stress drop and fault slip velocity}

Fig. 5 shows different $3 D E C$ models plotted in a stress drop - fault slip velocity diagram. The stress drop is a much debated quantity, which is difficult to measure and for which estimates for one and the same event usually agree only within a factor of 4 or 5 , depending on ambiguities in the underlying physics [14]. For the synthetic $3 D E C$ earthquakes it is trivial to calculate the actual change in shear stress at every point of the fault (cf. fig. 3, top) and then integrate over the rupture area to find the average stress drop. This gives about $15 \mathrm{MPa}$ for the M6.2 models, about $11 \mathrm{MPa}$ for the M5.5 models and 7-15 MPa for the M7.5 models. For real earthquakes one has to approximate the stress drop, for instance by the slip/width ratio as shown in the lower right inset of fig. 5 [14]. Making the same approximation for all earthquakes modeled here and comparing with corresponding stress drop approximation for the glacially induced earthquake in the Pärvie fault in northern Scandinavia suggests that four of the models displayed are well on the conservative side. The slip/width ratio for the Pärvie earthquake is based on estimates by Arvidsson [5] and Wood [12]. For the Uemachi fault and for the 1999 Chi-Chi earthquake it is based on models by Sekiguchi et al [15] and Ma et al [16], respectively.

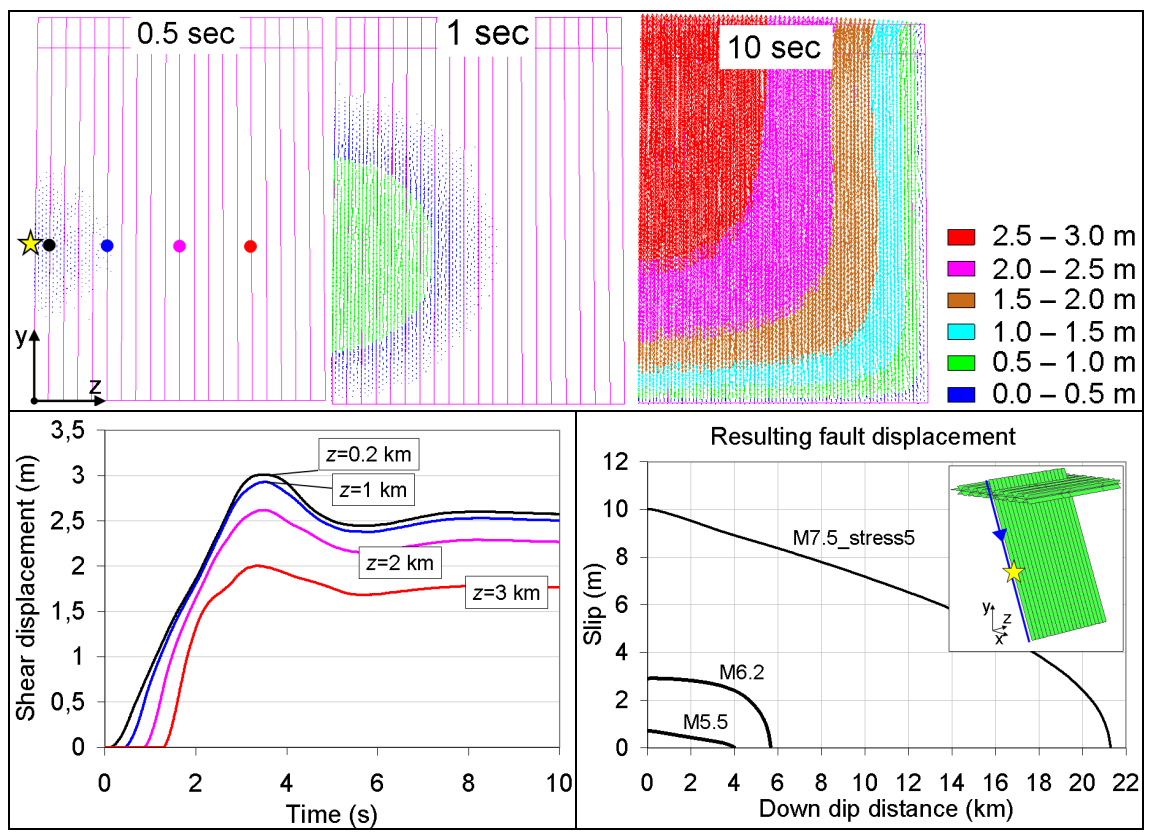

Figure 4: Top: fault slip vector plots at three instances of time in M6.2 model. Bottom left: fault slip histories in M6.2 model. Bottom right: resulting fault slip. 
There are no maximum slip velocity records of any of the glacially induced earthquakes in northern Scandinavia. In fig. 5 the $3 D E C$ maximum slip velocities are instead compared with data reported by Ma et al [17] for the 1999 Chi-Chi $\mathrm{M}_{\mathrm{w}} 7.6$ earthquake and with estimates based on data from Wald and Heaton [18] for the 1992 magnitude 7.2 Landers, California, earthquake. Note that ground stations around the Chi-Chi earthquake recorded the largest values of ground velocity ever instrumentally measured [17]. From fig. 5 it is clear that the fault slip velocities in many of the models are relatively high. Since the amplitude of a radiating stress wave can be regarded as proportional to the particle velocity at the source [9], the simulated earthquakes have relatively large impact on surrounding rock fractures.

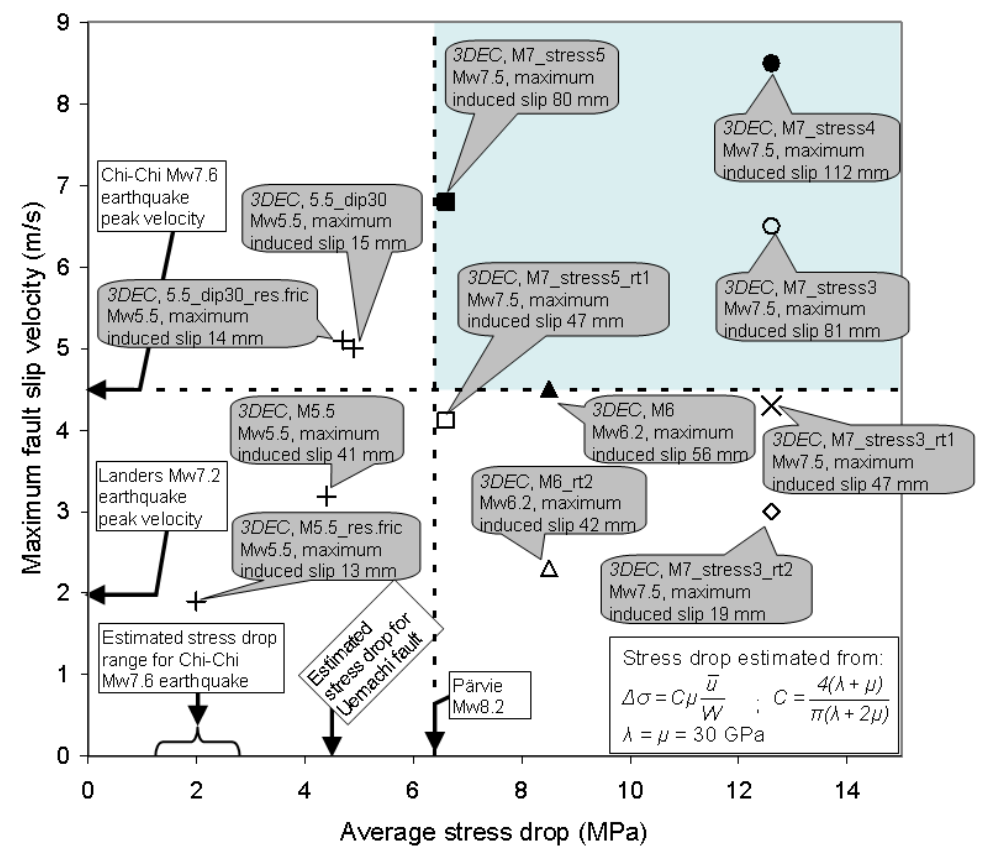

Figure 5: Comparing stress drop and fault peak slip velocities in the $3 D E C$ models with estimates based on literature data.

\subsection{Rock deformations, velocities and accelerations}

Fig. 6 shows a deformation vector plot in a vertical section close to the symmetry plane after $30 \mathrm{sec}$ in a M7.5 model. The three diagrams at the top show the temporal development of ground surface velocities and displacements at the points indicated. The point labels indicate the distance from the surface break of the fault. Due to the zero fault residual friction, there are still some movements (non-zero velocities) after $30 \mathrm{sec}$. The maximum rock displacement found in this 
model is about $6 \mathrm{~m}$ and the largest ground surface velocities are of the order of $100-150 \mathrm{~cm} / \mathrm{s}$.

The velocities in fig. 6 are in accordance with data found in the literature. According to a model by Wald and Heaton [18] the peak ground velocities during the 1992 Landers earthquake were about $100 \mathrm{~cm} / \mathrm{s}$ close to the fault. Stations close to the Chelungpu fault, Taiwan, recorded peak horizontal ground velocities in the range $50-300 \mathrm{~cm} / \mathrm{s}$ during the 1999 Chi-Chi earthquake [17].
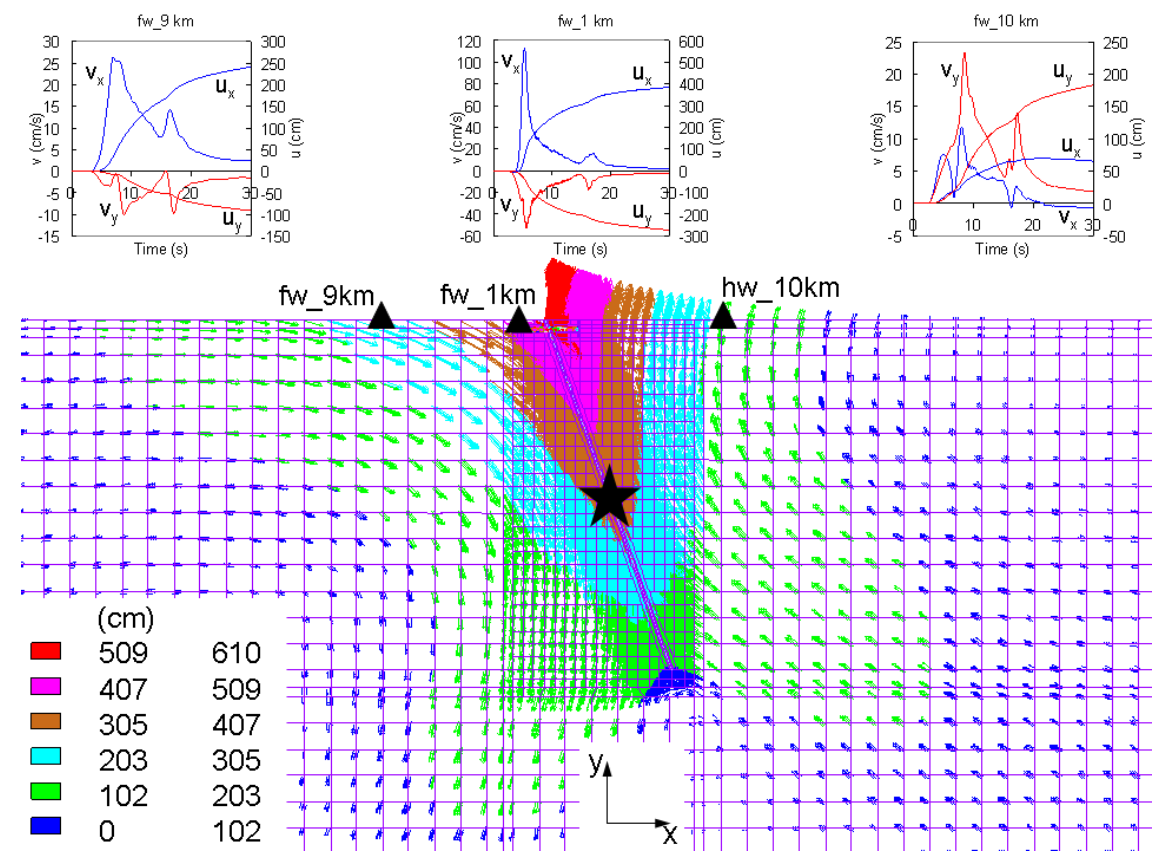

Figure 6: Bottom: vector plot of rock displacements after $30 \mathrm{~s}$ in a vertical section close to the symmetry plane in a M7.5 model. The asterisk indicates the hypocenter. Top: temporal development of ground velocities and displacements at the points indicated in the plot.

The attenuation of peak ground accelerations (PGA), peak ground velocities (PGV) and peak ground displacements (PGD) in the models were compared with empirical relations found in the literature. Fig. 7 shows the horizontal components of PGA, PGV and PGD in the M5.5 and M6.2 models plotted together with empirical relations developed by Campbell [19] and Skarlatoudis et al [20-22] scaled to the actual earthquake magnitude. The empirical relations are based primarily on data from small to moderate size earthquakes. The following general observations can be made:

- The model values follow two trends - one with higher values and one with lower. These correspond to recordings at the footwall and the hanging wall sides of the fault, respectively. 
- The models exaggerate the attenuation of PGA. However, at distances less than $2 \mathrm{~km}$ within the region of interest here, the agreement between models and empirical relations is reasonable. At $2 \mathrm{~km}$, the values may differ within half on an order of magnitude.

- The PGV values are in good agreement with the empirical relations, both at shorter and longer distances.

- The model PGD values are in general much higher than predicted by the empirical relations. At two km distance the values differ by about one order of magnitude or more.

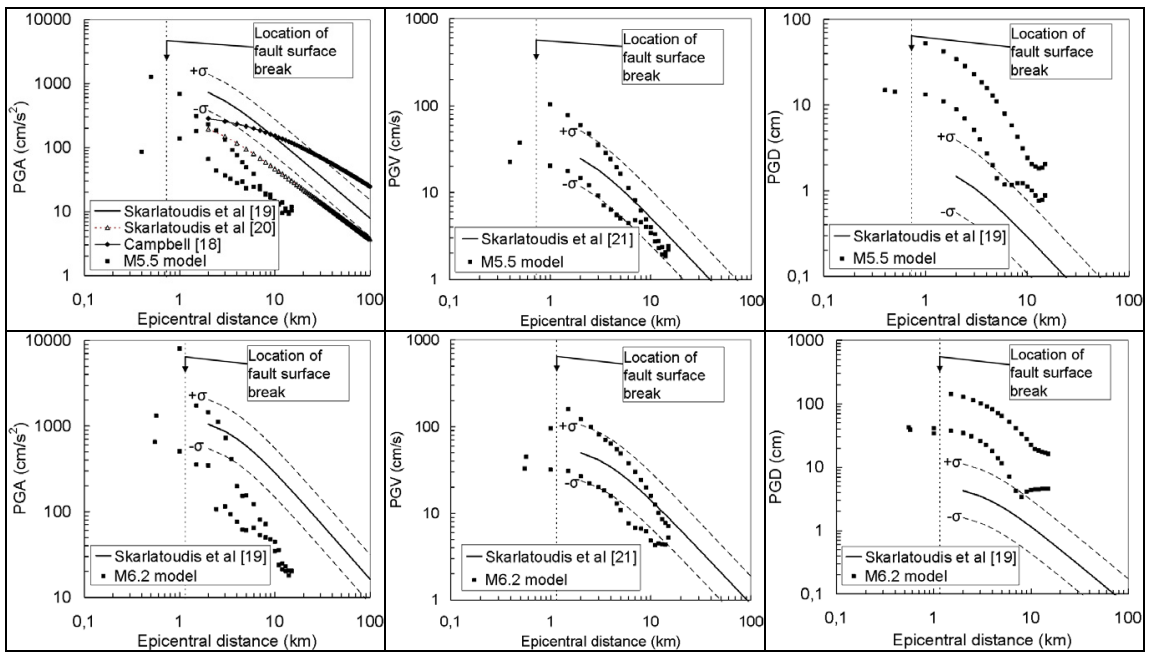

Figure 7: $\quad$ Comparison of PGA, PGV and PGD in the M5.5 and M6.2 models with empirical attenuation relations from Campbell [19] and Skarlatoudis et al [20-22] scaled to the actual earthquake magnitude. The $\pm 1 \sigma$-curves are from Skarlatoudis et al [20,22]. The location of the fault surface break is also indicated.

\subsection{Induced target fracture displacements}

Fig. 8 shows cumulated frequencies of induced target fracture shear displacements found in different models. The legends indicate fault-fracture distance, reduction time, $r t$, and different in-situ stress assumptions. Fault dip angle and fault residual strength other than the basic assumptions are also indicated. The top right shows the fault geometry and target fracture locations schematically. It can be observed that only one model gave target fracture displacements exceeding the $100 \mathrm{~mm}$ damage criterion. However, this particular model was an extreme one with a fault peak slip velocity about twice that of the largest slip velocity found for the 1999 Chi-Chi, Taiwan, earthquake $\left(M_{w} 7.6\right)$ [17] (cf. fig 5). 


\section{Summary and conclusions}

A generic modeling approach for estimating the possible static and dynamic effects of an earthquake on a deep repository for spent nuclear fuel has been presented. The following can be concluded:

- Fault movement: When stress drops and fault slip velocities in the models are compared with literature data from large real events it becomes clear that many of the models are conservative, both in terms of stress drop and fault slip velocity. Target fracture displacements obtained from these models are likely to be over-estimated. The most exaggerated $3 D E C$ model appeared to have a maximum fault slip velocity that was about twice as high as that reported for the 1999 Chi-Chi, Taiwan, earthquake, known to have produced the highest ground velocities ever instrumentally measured. For models with values of the peak fault slip velocity on level with or smaller than that of the Chi-Chi earthquake, for instance, target fracture displacements were found to be about $50 \mathrm{~mm}$ at maximum.

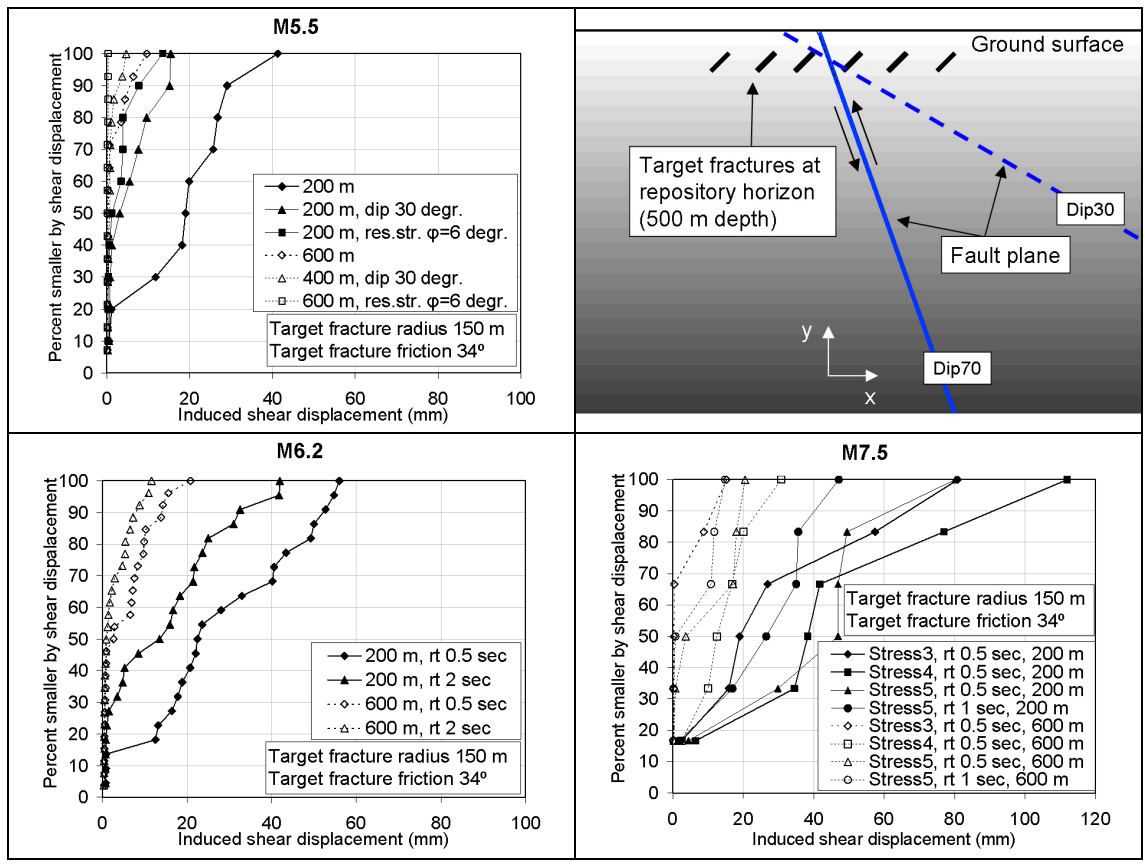

Figure 8: Cumulated frequencies of induced target fracture displacement. The legends indicate fault-fracture distance, reduction time $r t$ and different in-situ stress assumptions. Fault dip angle and fault residual strength other than the basic assumptions are also indicated. The top right is a schematic sketch of fault geometry and target fracture locations. 
- Ground motions: The ground velocities recorded in the models are of the same order as those observed during real events. The attenuation of PGV also seems to be in accordance with empirical relations whereas the models tend to under-estimate the PGA values and over-estimate the PGD values.

The generic earthquake models presented here are idealized both in terms of stress drop distribution, fault slip distribution and in the way the fault rupture is represented. However, the comparison between model data and literature data made here indicates that the models produce velocities and displacements that are in agreement with those observed in real earthquakes. This seems to support the supposition that the models are relevant for their purpose, namely to simulate the possible static and dynamic effects of a large earthquake on rock fractures in its near field.

\section{References}

[1] SKB, Long-term safety for KBS-3 repositories at Forsmark and Laxemar a first evaluation. Main report of the SR-Can project. SKB TR-06-09, Svensk Kärnbränslehantering AB: Stockholm, 2006.

[2] Slunga, R.S., The Baltic Shield Earthquakes, Tectonophysics 189, pp. 323331, 1991.

[3] Bödvarsson, R., Lund B., Roberts R. \& Slunga R., Earthquake activity in Sweden. Study in connection with a proposed nuclear waste repository in Forsmark or Oskarshamn. SKB R-06-67, Svensk Kärnbränslehantering AB: Stockholm, 2006.

[4] Lagerbäck, R., Postglacial faulting and paleoseismicity in the Lansjärv area, northern Sweden. SKB TR-88-25, Svensk Kärnbränslehantering AB: Stockholm, 1998.

[5] Arvidsson, R., Fennoscandian Earthquakes: Whole Crustal Rupturing Related to Postglacial Rebound, Science 274, pp. 744-746, 1996.

[6] Munier, R. \& Hökmark H., Respect distances. Rationale and means of computation. SKB R-04-17, Svensk Kärnbränslehantering AB: Stockholm, 2004.

[7] Fälth, B. \& Hökmark, H., Seismically induced slip on rock fractures. Results from dynamic discrete fracture modeling, SKB R-06-48, Svensk Kärnbränslehantering AB: Stockholm, 2006.

[8] Fälth, B. \& Hökmark H., Effects of large earthquakes on a KBS-3 repository. Evaluation of modelling results and their implications for layout and design. SKB TR-08-11, In prep. Stockholm: Svensk Kärnbränslehantering AB, 2009.

[9] Itasca Consulting Group Inc., 3DEC - 3-Dimensional Distinct Element Code, User's Guide, Itasca Consulting Group Inc.: Minneapolis, 2003.

[10] SKB, Preliminary site description. Forsmark area - version 1.2. SKB R-0518, Svensk Kärnbränslehantering AB: Stockholm, 2005.

[11] SKB, Preliminary site description. Laxemar subarea - version 1.2. SKB R06-10, Svensk Kärnbränslehantering AB: Stockholm, 2006. 
[12] Muir Wood, R., A review of the seismotectonics of Sweden. SKB TR-93-13, Svensk Kärnbränslehantering AB: Stockholm, 1993.

[13] Lund, B., Stress variations during a glacial cycle at $500 \mathrm{~m}$ depth in Forsmark and Oskarshamn: Earth model effects. SKB R-06-95, Svensk Kärnbränslehantering AB: Stockholm, 2006.

[14] Scholz, C., The mechanics of earthquakes and faulting. 2nd ed., Cambridge University Press: Cambridge, 2002.

[15] Sekiguchi, H., Horikawa, H., Kase, Y., Ishiyama, T., Satake, K., Sugiyama, Y. \& Mizuno, K., Ground motion prediction in Osaka Basin, central Japan, based on geological, geophysical and paleoseismological data and numerical simulations of earthquake rupture and ground motion, Proc. of the $13^{\text {th }}$ World Conference on Earthquake Engineering, Vancouver, B.C., Canada, 2004.

[16] Ma, K.F., Mori, J., Lee, S.J. \& Yu, S.B., Spatial and temporal distribution of slip for the 1999 Chi-Chi, Taiwan, earthquake, Bull. Seism. Soc. Am., 91(5) pp. 1069-1087, 2001.

[17] Ma, K.F., Brodsky, E.E., Mori, J., Ji, C., Song, T.R.A. \& Kanamori, H., Evidence for fault lubrication during the 1999 Chi-Chi, Taiwan, earthquake (Mw7.6), Geophysical research letters, 30(5), 1244, doi: 10.1029/2002GL015380, 2003.

[18] Wald, D.J. \& Heaton, T.H., Spatial and Temporal Distribution of Slip for the 1992 Landers, California, Earthquake, Bull. Seism. Soc. Am., 84(3) pp. 668691, 1994.

[19] Campbell, K.W., The dependence of peak horizontal acceleration on magnitude, distance and site effects for small magnitude earthquakes in California and Eastern North America, Bull. Seism. Soc. Am., 79(5), pp. 1311-1346, 1989.

[20] Skarlatoudis, A.A., Papazachos, C.B., Margaris, B.N., Theodulidis, N., Papaioannou, C., Kalogeras, I., Scordilis, E.M. \& Karakostas, V., Empirical peak ground motion predictive relations for shallow earthquakes in Greece, Bull. Seism. Soc. Am., 93(6) pp. 2591-2603, 2003.

[21] Skarlatoudis, A.A., Theodulidis, N., Papaioannou, C. \& Roumelioti, Z., The dependence of peak horizontal acceleration on magnitude and distance for small magnitude earthquakes in Greece. Proc. of the $13^{\text {th }}$ World Conference on Earthquake Engineering, Vancouver, B.C., Canada, 2004.

[22] Skarlatoudis, A.A., Papazachos, C.B., Margaris, B.N., Theodulidis, N., Papaioannou, C., Kalogeras, I., Scordilis, E.M. \& Karakostas, V., Erratum to Empirical peak ground motion predictive relations for shallow earthquakes in Greece, Bull. Seism. Soc. Am., 97(6) pp. 2219-2221, 2007. 